\title{
Proposal to Improve the Ground Water Potential In and Around Devarayapuram Village
}

\author{
Seenivasan G.R ${ }^{1}$, Balasubramanian $\mathrm{S}^{2}$, Lingaeswar $\mathrm{D}^{3}$, Vignesh $\mathrm{B}^{4}$ \\ Assistant Professor, Department of Civil Engineering, \\ Coimbatore institute of Engineering and Technology, \\ Coimbatore, Tamilnadu, India.
}

\begin{abstract}
Devarayapuram and surrounding villages situated at the foot of Western Ghats, about $20 \mathrm{~km}$ west of Coimbatore is mainly depending upon Agriculture. Dry crop farming is the only source for the people in these areas, as there is no perennial water source. The Noyyal River which flows eastwards from the Western Ghats, feeds the lands on the southern banks and a small area on the upper reaches. The geological formation of this area also does not permit this river to feed the lands between foot of perumalmudi hills and the north bank of the river. The people in these areas are mainly depending upon the dry farm cultivation only and a farmer has gone in to tap the ground water vigorously now a days. The ground water table which was at 100 feet below ground level in the year 1985 has gone down to 500 feet this year. The farming activities have considerably reduced due to the above reasons and the farm labourers are forced to go in for search of jobs in the nearby town Coimbatore, some unskilled works for merge wages. Unless a suitable solution is found for this, the people may find it difficult to earn their livelihood in the near future, and the entire population may have to go out in search of jobs in other places. The people in these areas are known for their hardworking and farming activities. Since water source is not available in this area, the people are completely depending only on ground water, and that too has gone down in the recent years and may vanish in near future. Hence a suitable arrangement to improve the ground water in these areas is the need of the people.
\end{abstract}

Keywords: Ground water recharge, agriculture, check dams, rainfall, catchment area

\section{Introduction}

Check dams is necessary to reduce irrigation water shortages in the future. Water harvesting using smaller dams has the potential to transform infertile dry lands to productive agricultural lands, recharge groundwater, sustain ecology, and ultimately alleviate poverty among rural communities in India. Even silt is not a problem since using additional techniques for silt removal. Check dams constructed near forest areas provide water during the dry season to large numbers of wildlife. Usually only the flow of water from the rainy season is harvested in check dam. Check dams would also recharge groundwater, supplying local wells and pore wells. Thus the role of check dams highlighted here is simple, natural, and cost-effective. If a check-dam strategy is implemented across the vast dry lands of India and elsewhere in the developing our country, it could not only help minimize future water conflicts, but also increase agricultural output, guarantee rural food security, enhance groundwater resources, and potentially reduce poverty.

\subsection{Introduction of Ground Water}

\section{Ground Water}

Underground water includes all water that occurs below the earth's surface, occupying interstices or voids of pervious rocks and soil; like surface water, it is derived principally from precipitation that falls upon the earth's surface and percolates downward under gravity. Underground water in the zone of saturation may occur in either water table (unconfined) aquifers or artesian (confined) aquifers. Confined water is generally under pressure greater than atmospheric pressure, and wells penetrating a confined aquifer will permit water to rise above the confining strata. If sufficient pressure exists flowing wells may result. In the case of water table aquifers, water is derived from local precipitation; but in the case of artesian wells, water may enter the permeable strata ten or even hundreds of miles from the point where it is intercepted by wells; hence, water taken from a well is no more a part of the land than is the water of a surface stream that crosses it.

In addition to municipal and irrigation uses, many industries have developed underground water supplies for cooling and industrial processes. Characteristics of underground water that make it particularly desirable for industry are its uniform temperature and uniform quality at a given source. Although all underground water contains mineral matter derived principally from soil and rocks through which it moves, its quality and temperature will generally remain constant at a given locality unless it is contaminated by human activities. 
Nearly all of the geologic formations in the state yield some water, generally in sufficient quantities for domestic and livestock purposes. Where it is available in sufficient quantities, underground water is generally cheapest to develop, since it does not need the extensive by pipelines and treatments facilities require for surface supplies. Unlike surface water, which flows in defined and limited channels, underground water can often be developed at the point of use, requiring little or no transportation.

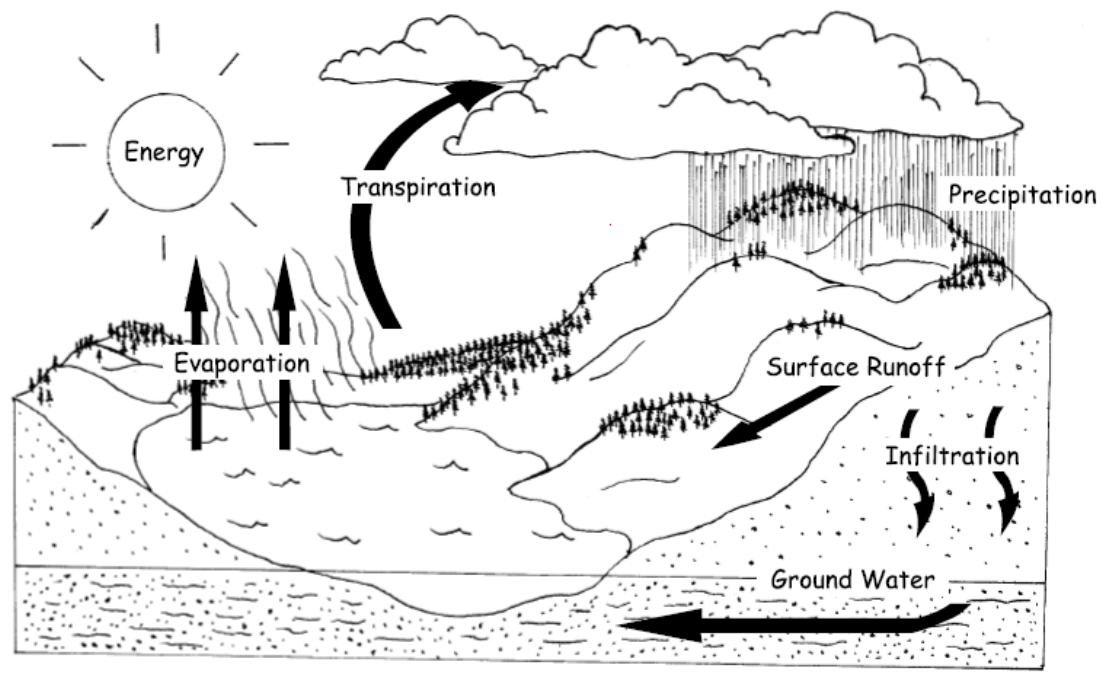

Figure: 1. Water Cycle

\subsection{Solution for Ground Water Recharge}

Construction of check dam in this area is the only solution to increase the ground water potential. Water harvested by the check dam increase the income of livelihoods mainly due to sustained agriculture and increased availability of water for various uses.

\subsection{Definition and purpose:}

\section{Check Dams}

Check dams are constructed of rock, sediment retention fibre rolls, gravel bags, sandbags, or other proprietary product placed across a natural or manmade channel or drainage ditch. A properly designed, constructed, and maintained check dam will reduce scour and channel erosion by reducing flow velocity and encouraging sedimentation. Check dams in conjunction with sediment basins are usually able to capture a large percentage of the sediments suspended in the water.

\subsection{Appropriate applications:}

A check dam either filters the water for sediment as it passes through the dam or retains the water, allowing the sediment to settle while the water flows over the dam. Check dams may be installed:

$>$ In small open channels.

$>$ During the establishment of grass linings in drainage ditches or channels.

$>$ In temporary ditches where the short length of service does not warrant establishment of erosion-resistant linings.

\subsection{Data Collection About Check Dam}

$>$ Ground water details

$>$ Rainfall details

$>$ Catchment area

$>$ Area of check dam

\subsection{Project location:}

Near Muthukaruparayan temple, Vellarugampalayam village, Devayapuram panchayat, Thondamuthur taluk, Coimbatore District

\subsection{Impounds:}

- Perumpallam Stream

- Itchikuli Stream 


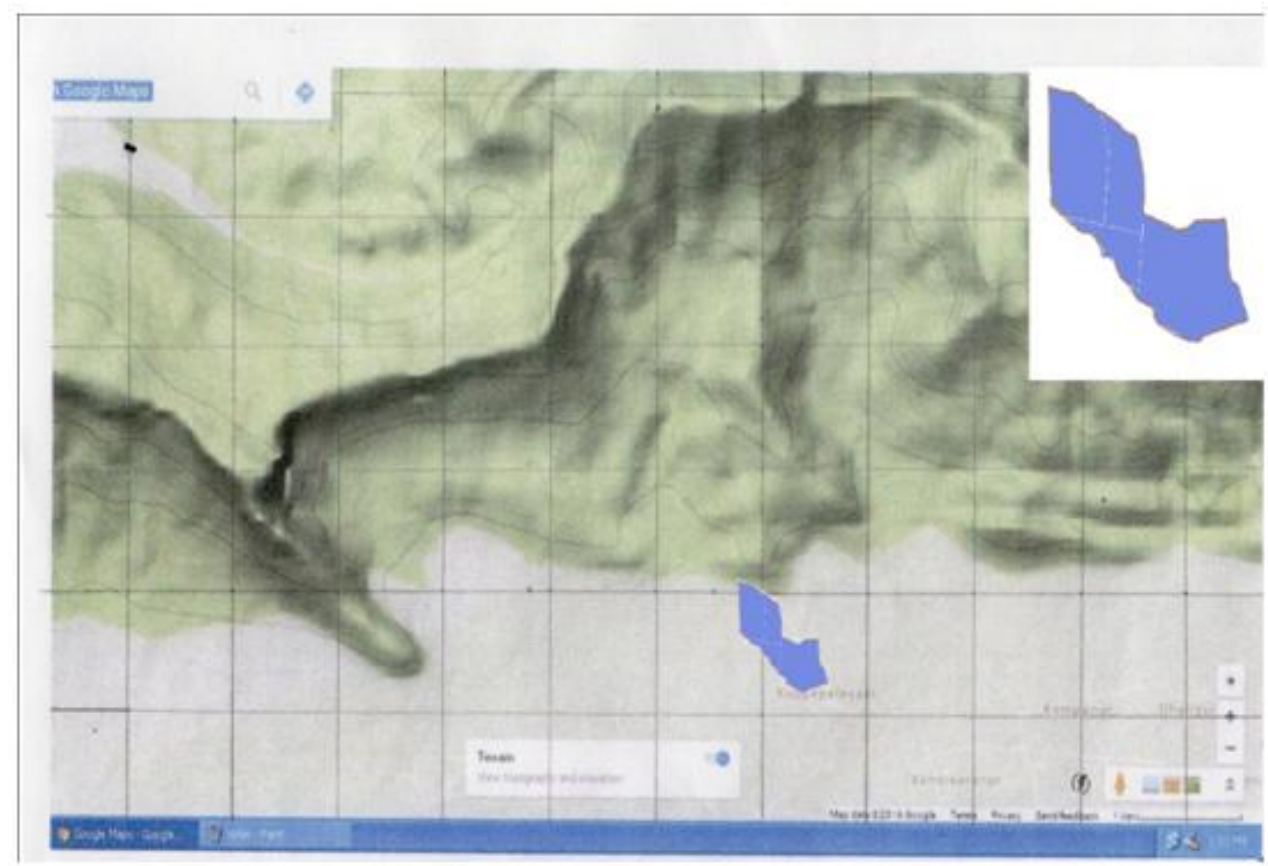

Figure: 2 Project location Map

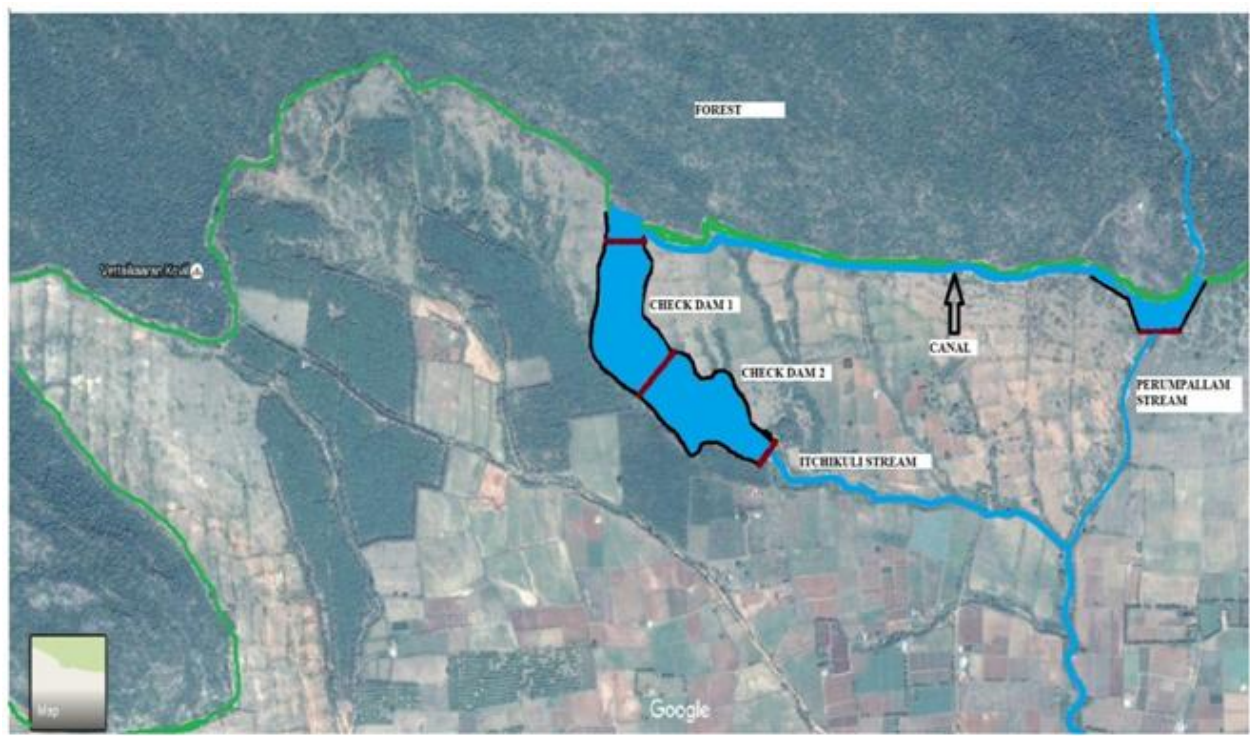

Figure: 2.1 Satellite Map of the Location

\section{Design Parameters}

$>$ The size of the area to be drained, the gradient or slope of the ditch and anticipated high velocity runoff must all be considered when choosing the appropriate type of check dam.

$>$ Rock check dams are usually the most effective to use, but the correct rock size and combination must be available and installed properly. Rock size should vary from 1 inch to 8 inches, with 8 inches making up 30 percent or more of the mix.

$>$ Check dams shall be placed at a distance and height to allow small pools to form behind them. The check dams shall be installed approximately 6 feet from the outfall device and at regular intervals based on slope gradient and soil type.

$>$ For installation of multiple check dams, backwater from downstream check dam shall reach the toe of the upstream dam. On steep slopes, typically greater than $3 \mathrm{H}: 1 \mathrm{~V}$, the spacing will become so close that consideration should be given to using a slope drain (rock lined or pipe) instead of a check dam (see EC-5, Slope Drains). 
$>$ The centre of the check dam should be 6 to 10 inches lower than the top of the outside edge to form a weir for the overflow. The top of the outside edges should be at least 6 inches lower than the roadway, banks, or back slope to prevent water from flowing onto the roadway or undercutting the banks.

$>$ High flows shall safely flow over the check dam without an increase in upstream flooding or damage to the check dam.

$>$ Undercutting shall always be considered, regardless of the type of check dam being used. For rock check dams, a geotextile shall be placed under the bottom of the dam. For sediment retention fiber rolls, a trench ( 3 to 5 inches deep) shall be dug to key in the roll. Excavated soil shall be placed on the upstream side of the wattle and compact. The fibre rolls shall be anchored with wood stakes according to manufacturer's recommendations.

$>$ Where grass is used to line ditches, check dams may be removed when grass has matured sufficiently to protect the ditch or swale.

$>$ Rock shall be placed individually by hand or by mechanical means, but should not be dumped to achieve complete ditch or swale coverage.

$>$ Stable inlets and outlets shall be designed and constructed prior to installation of check dams.

$>$ If straw bales are used, the bales shall be placed in a trench backfilled on the upstream side and compacted Rock 1 to 3 inches shall be placed in the overflow area both upstream and downstream (similar to a rock check dam) to provide additional stability and strength. An overflow shall be formed in the centre of straw bale check dams.

$>$ Careful inspection is important during installation of check dams and channel liners. Refer to special contract provisions or plans to ensure that check dams and liners are installed and perform properly during their lifetime.

$>$ Field adjustments shall be made as necessary to ensure proper performance.

\section{Coimbatore District Mean Annual Rainfall}

The long term mean annual rainfall of the district is $1242.49 \mathrm{~mm}$. The district is characterized with unique aerial topography (Fig.4) in quantum of rainfall due to the influence of western Ghat and Anaimalai and Nilgiri hills. The maximum rainfall recorded at Upper Niradam which is $4655.1 \mathrm{~mm}$ and minimum $414.4 \mathrm{~mm}$ at Krishnapuram. The southern part of region experiences highest rainfall that is Upper Niradam $(4655.1 \mathrm{~mm})$,Solaiyar Nagar $(3703 \mathrm{~mm})$,Anaimalai $(3523.3 \mathrm{~mm})$, Valparai $(2882.7 \mathrm{~mm})$, these places influenced by the Western Ghats windward and located at Anaimalai reserve forest part of Western Ghats and gradually decreases toward north, east, north east upland region. Whereas Krishnapuram (414.4mm),Annur. (559mm), Coimbatore town $(559.3 \mathrm{~mm})$, Sultanpet $(577.3 \mathrm{~mm})$, sulur $(577.5 \mathrm{~mm})$, these upland region and palaghat gap are rain shadow regions experiences lowest of rainfall in district. In general south, south west and north western parts noticed the heavy rainfall, the region falls under following zones.

\subsection{High rainfall zone: (above $1000 \mathrm{~mm})$ :}

In the southern part Upper Niradam, Soliyar Nagar,Anaimalai, Valaparai, Topslip, Attakatti, in the north western part Anaikatti, coonoor, Ooty, Kodanadu, Kethi, Kotagiri and sudakapalaya in the north eastern part.

\subsection{Moderate rainfall zone $(800-999 \mathrm{~mm})$ :}

Pollachi, P.N.Palayam, Aliyar Nagar, Negamam,

\subsection{Normal rainfall zone :( 700-799mm):}

Mettupalyam Tirumoorthy Nagar, Nallar colony.

5.4. Low rainfall zones: $(600-699 \mathrm{~mm})$ :

Vettaikarnpudur, Podanur, Chitrachavadi, and Bhavanisag

5.5. Very low rainfall zones :( Less than 600):

Annur, Pedamapatti, Coimbatore town, Palladam, Peelamedu, Krrishanpuram, Poolankinar, Sultanpet and Sulur. 

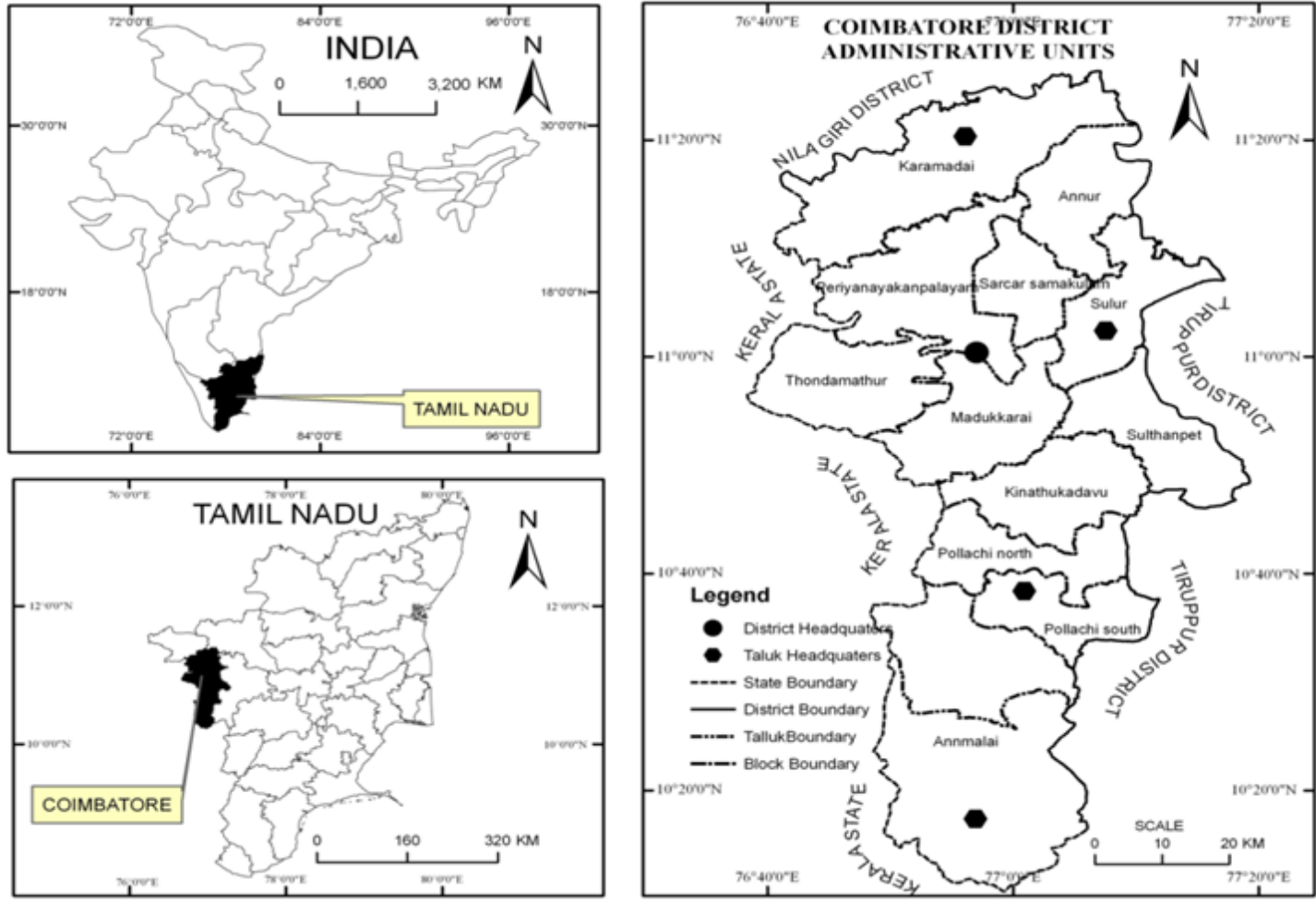

Figure: 4 Coimbatore district Map

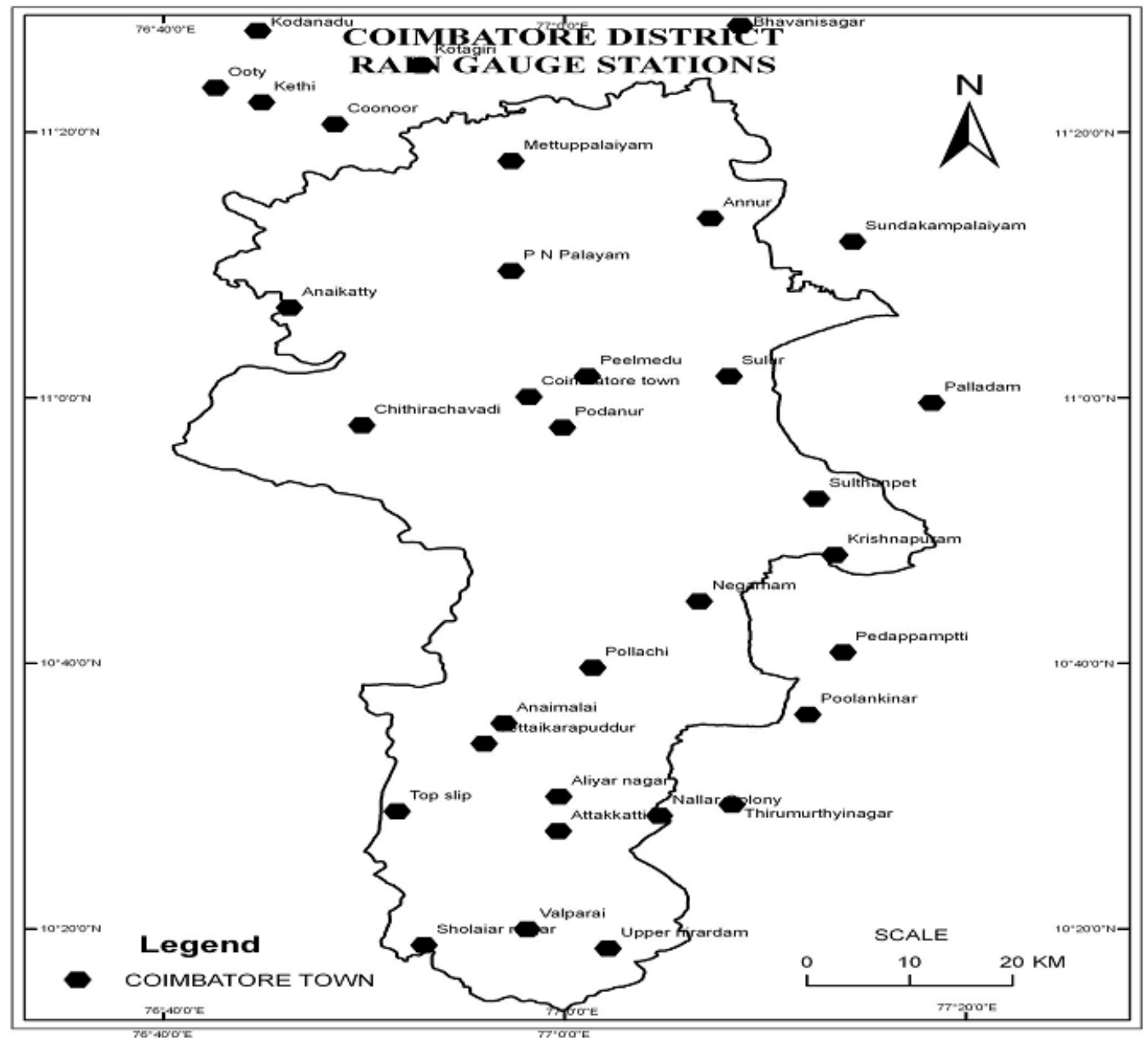

Figure: 5 Coimbatore district rain gauge stations 


\section{Calculation Of Catchment Area}

Area of one grid square

$=1 \mathrm{~km} \times 1 \mathrm{~km}=1 \mathrm{~km}^{2}$

Number of grid square

Area of 6 nos of grid square

$=6$ nos

Size of the grid square

$=6 \times 1=6 \mathrm{~km}^{2}$

$(2.2 \mathrm{~cm}$ represents $1 \mathrm{~km})$

$=2.2 \mathrm{~cm} \times 2.2 \mathrm{~cm}$

Therefore $1 \mathrm{~mm}$ will be equal to $45450 \mathrm{~mm}$

Area of triangle A

Catchment area in the $7^{\text {th }}$ grid square

$=1 / 2(2 \mathrm{~cm} \mathrm{x} 0.9 \mathrm{~cm}) \times 0.4545^{2}$

$=0.1859 \mathrm{~km}^{2}$

= Area of grid square- area of triangle A

$=1 \mathrm{~km}^{2}-0.1859 \mathrm{~km}^{2}$

$=0.814 \mathrm{~km}^{2}$

Catchment area in $8^{\text {th }}$ grid square

$=$ Area of triangle $\mathrm{B}$

$=1 / 2 \times(1.2 \mathrm{~cm} \times 2 \mathrm{~cm}) \times 0.4545^{2}$

$=0.248 \mathrm{~km}^{2}$

Catchment area in $9^{\text {th }} \& 10^{\text {th }}$ grid square

$=2 \times(0.5 \mathrm{~cm} \times 2.2 \mathrm{~cm}) \times 0.4545^{2}$

$=0.454 \mathrm{~km}^{2}$

$=33.049$ acres

$=0.134 \mathrm{~km}^{2}$

Total catchment area

$=6+0.814+0.248+0.454+0.134$

$=7.65 \mathrm{~km}^{2}$

$=7.65 \times 10^{6} \mathrm{~m}^{2}$

$=7.65 \times 10^{6} \mathrm{~m}^{2}$

\section{Catchment area of the check dam}

\section{Calculation Of Mean Annual Runoff In The Catchment}

Chitrachavadi rain gauge station is the rain gauge stations in Thondamuthur taluk

Mean annual rainfall in chitrachavadi

$=657.10 \mathrm{~mm}$

Mean annual rainfall in meter

$$
=0.6571 \mathrm{~m}
$$

\begin{tabular}{|l|l|l|}
\hline S.No. & AREA & COEFFICIENT \\
\hline 1 & Roof catchments:Tiles & $0.8-0.9$ \\
\hline 2 & Ground surface coverings - Concrete & $0.6-0.8$ \\
\hline 3 & Brick pavement & $0.5-0.6$ \\
\hline 4 & Untreated ground catchments'-Soil on slopes less than 10 percent & $0.0-0.3$ \\
\hline 5 & Corrugated metal sheets & $0.7-0.9$ \\
\hline 6 & Rocky natural catchments & $0.2-0.5$ \\
\hline
\end{tabular}

Source : The collection of rainfall and runoff in rural areas by Pacey, Arnold and cullis, Adrain

\section{Runoff coefficient}

The runoff coefficient $(\mathrm{C})$ is a dimensionless coefficient relating the amount of runoff to the amount of precipitation received. It is a larger value for areas with low infiltration and high runoff (pavement, steep gradient), and lower for permeable, well vegetated areas (forest, flat land).

Mean annual runoff in the catchment $=$ Mean annual rainfall in $\mathrm{m} x$ Catchment area in $\mathrm{m}^{2} \mathrm{x}$ Run off coefficient

Mean annual runoff in the catchment $=25761375.5 \mathrm{~m}^{3}$

$$
\begin{aligned}
& =0.6735 \times\left(7.65 \times 10^{6)} \times 0.5\right. \\
& =25761375.5 \mathrm{~m}^{3}
\end{aligned}
$$

\section{Conclusion}

The review of research work on assessing the impact of check dam as a method of improving the groundwater level, groundwater quality and socio economic aspects was carried out. It is from evident from all the studies that groundwater potential increase due to the construction of check dams. Efficiency of the check dam will be at its best by adopting proper maintenance activities such as silt removal and bed scratching at periodical intervals. To overcome the problem of reduction of recharge due to silting, water from the check dam can be released at periodical intervals so as to increase the recharge through the downstream side. It is generally observed by many researchers that groundwater quality improves within the vicinity of the check dam. However, the aerial extent of influence of check dam varies depending on the geology, hydrogeology as well as the storage capacity. However, improvement in groundwater quality depends on the quality of water stored by 
the check dam. It is important to maintain the quality of water by taking suitable precautions like preventing discharge from the nearby agricultural lands, release of domestic wastes, sewage, dumping of wastes etc. Water harvested by the check dam increase the income of livelihoods mainly due to sustained agriculture and increased availability of water for various uses. It is concluded stored storm water through check dam is found to be one of the efficient method to improve the groundwater potential.

\section{References}

[1]. Spatial Analysis of Rainfall Variation in Coimbatore District Tamilnadu using GIS. By S.Aruchamy, International journal of geomatics and geosciences Volume 1, No 2, 2010

[2]. Rainwater harvesting: The collection of rainfall and runoff in rural areas by Pacey, Arnold and cullis, Adrain 1989, Intermediate Technology Publications, London

[3]. Silt ejection at Diversion head works. Irrigation engineering 2011 by H.M Raghunath, Formerly professor, dept of civil engineering, G.B.Pant university of Agriculture and technology, Chennai. 